\title{
Strategic Responses to Institutional Voids (Rationalization, Aggression, and Defensiveness): Institutional Complementarity and Why the Home Country Matters
}

\author{
John M. Luiz ${ }^{1,2}$ (D) Takudzwa Magada ${ }^{3} \cdot$ Regis Mukumbuzi ${ }^{3}$
}

Received: 16 January 2021 / Revised: 1 November 2021 / Accepted: 15 November 2021 /

Published online: 15 December 2021

(c) The Author(s) 2021

\begin{abstract}
We seek to understand how the strategic responses of firms to institutional voids are affected by their home countries' institutional contexts. It adopts an exploratory, multiple case studies approach examining the responses of advanced and emerging multinational enterprises, and local firms in two African countries which are characterized by such voids, namely the Democratic Republic of the Congo and Zimbabwe. Our research suggests that firms' strategic responses to institutional voids in emerging or developing markets are affected by the home country's institutional environment and firms' experiences and advantages arising from that home context. Firms adopt strategic responses which reflect their respective advantages and this results in diverse approaches based on the interplay between capitalizing upon internal resources and institutional know-how. For some firms this may result in a defensive strategic response, whilst for others opportunistic and aggressive agility, or rationalization and reconciliation may manifest. We demonstrate differences between advanced and emerging multinational enterprises and domestic firms covering the spectrum between institutional outsiders and insiders. We emphasize the contextual nature of these strategic responses and argue that this requires integrating both a resource and institution-based analysis of firms' underlying advantages and how they are able to leverage off these advantages in institutionally voided environments. Practical implications arise for doing business in emerging and developing markets.
\end{abstract}

Keywords Strategic responses - Institutional voids · Institutional complementarity · Qualitative research · Democratic Republic of the Congo and Zimbabwe · Africa

John M. Luiz

johnluiz@hotmail.com; J.M.Luiz@sussex.ac.uk

1 University of Sussex Business School, Jubilee Building, Brighton BN1 9SL, UK

2 University of Cape Town, Cape Town, South Africa

3 Graduate School of Business, University of Cape Town, Cape Town, South Africa 


\section{Introduction}

The global economy has experienced substantial shifts in terms of economic output and trade flows, with the growing importance of emerging markets and the declining share of advanced economies (Liedong et al., 2020). Whilst we have seen a mounting literature on emerging markets, this has been limited in terms of geographical coverage, and Fainshmidt et al. (2018) argue that there are a large group of understudied economies within the developing world that have diverse and unique institutional environments. They lament that with the growth of developing economies, research has not kept pace with understanding institutional contexts for vast parts of the world. We respond to this by focusing here on examining the institutional environment in two understudied countries with fragmented institutional systems and fragile states, to use their terminology, and examine how such contexts affects the strategic responses of firms. This will be of increasing importance to international business studies in the future as more such countries become investment targets.

Emerging and developing markets are often presented as being beset by institutional voids (Gao et al., 2017). It is argued that in the presence of these voids the environment of business may become turbulent, costly, and unpredictable, making it difficult to plan, manage transaction costs, and create stable long-term strategies for profitability (Khanna \& Palepu, 2010). Faced with conditions of sustained institutional voids, firms, particularly foreign multinational enterprises (MNEs), may end up fleeing the host country to seek more stable environments (Barnard \& Luiz, 2018; Cuervo-Cazurra et al., 2018a, b; Holburn \& Zelner, 2010). Those that remain face higher transaction costs associated with these voids and the lack of predictability and security of investment means that they have to develop mitigating strategies and unique capabilities to succeed in these settings. Firms therefore have a range of possible responses to host country institutional voids and we ask whether those responses may be affected by the institutional environment of their home country by building on prior literature on the effects of a firm's home country on internationalization (Cazurra et al., 2018b; García-Canal \& Guillén, 2008; Hoskisson et al., 2013).

Gao et al. (2017, p. 2148) argue that 'institutions are more than just background conditions' and that they directly impact the strategic responses available to firms. They state that 'firms can achieve and sustain competitive advantage through strategies that overcome, shape, and capitalize on the nature of the institutional environments'. Extant research in international business explores the relationship between institutional voids and firm outcomes as well as how they affect the motives for, timing of, and selected entry modes (Aguilera \& Grøgaard, 2019; Kostova et al., 2019; Meyer et al., 2009).

Our approach is narrower and focuses on firms that operate in environments of institutional voids and seeks to understand how their strategic responses to these voids are affected by their home countries' institutional contexts. It adopts an exploratory, qualitative methods approach in two African countries which are 
characterized by such voids (as per Khanna \& Palepu, 2010), namely the Democratic Republic of the Congo (DRC) and Zimbabwe.

We provide additional insights into three strands of research. Firstly, the impact of institutional voids on firms' behavior in emerging markets (Khanna \& Palepu, 2010; Wang et al., 2020) and we extend this towards less developed markets by demonstrating the diverse responses of firms to such voids and we provide some explanation for why these responses may vary. Secondly, the literature on the effects of a firm's home country on internationalization (Geleilate et al., 2016; Hoskisson et al., 2013; Luo \& Wang, 2012). Cuervo-Cazurra et al. (2018b, p. 593) state that surprisingly ' $[\mathrm{M}]$ any of the current theories and models of the multinational have paid limited attention to the influence of the multinational's home country'. Likewise, Adomako et al. (2020) lament the lack of consideration given to the critical role of home countries' institutional environments in driving international expansion and they focus on how it influences and moderates the relationship between perceived environmental uncertainty and the patterns of internationalization. We highlight how the home country may influence the strategic responses of firms to institutional voids in particular. Lastly, we contribute towards the study of firms in underdeveloped countries, particularly in Africa, which remains underresearched (Boso et al., 2019; Chen et al., 2017; Mol et al., 2017). Not only do we need to have a better sense of how existing research translates into institutionally voided, low income regions which may feature more prominently in the future as they develop further, but also by focusing on more extreme institutional settings we follow the advice of Barnard et al. (2017) about the value of theorizing from extreme conditions.

The paper is structured as follows. We proceed by reviewing the theoretical arguments around the impact of institutional voids on the strategic responses of firms and why the home country institutional context may matter in this regard. This is followed by an overview of the research methodology. The results and discussion follow. We conclude by discussing the theoretical and practical implications of our study, the limitations, and areas for future research.

\section{Theoretical Background}

\subsection{Institutional Voids in Emerging and Developing Markets ${ }^{1}$}

Institutions are the collective rules, laws, regulations, norms and conventions or rules of the game that underpin the economic environment (North, 1990). The

\footnotetext{
${ }^{1}$ The term institutional voids is not uncontested as it implies institutional 'nothingness' and of course institutions exist within even the most problematic institutional environments within emerging markets (see Hamann et al., 2020). We accept this argument and that the term void may be overly extreme but we utilise it in this paper given its wide use within international business research but caution against the perception of nothingness. Rather we use the term to describe gaps in the institutional environment or inefficient market-supporting institutions as per Khanna and Palepu (2010). Also our two country host contexts would generally fall into lower income country categories as classified by the World Bank (2019) and would not necessarily spring to mind in terms of emerging markets but we use the emerging market term as an extension of Khanna and Palepu's (2010) equating of emerging markets as 'transactional arenas' where institutional deficiencies dominate. We return to this in the methodology section.
} 
inherent differences in the nature of institutional arrangements from one country to the other has an influence on the level of economic activity and can present both opportunities and constraints for doing business there (Adomako et al., 2019; Cuervo-Cazurra et al., 2019; Liu \& Li, 2019). Within international business research, the role of institutional context is pivotal to understanding firm behavior and success. Furthermore, because of the increasing focus on emerging and developing markets and the prevalence of voids in many such economies it is all the more important to comprehend their impact.

Khanna and Palepu (2010) describe institutional voids as missing or inefficient market-supporting institutions necessary to complete transactions in an economy. They equate emerging markets as 'transactional arenas' where these structural deficiencies dominate and argue that the preponderance of these are located in developing countries. These countries are often beset by weak national governance structures, inefficient judiciaries, a lack of independent checks and balances, ineffective regulatory systems, poor infrastructure, and significant information asymmetries which complicate contracting and exchange (Gao et al., 2017). These voids 'hamper market interactions, increase transaction costs, cause economic inefficiency (Khanna \& Palepu, 1997) and subsequently shape firms' resource commitments in foreign markets' (Liedong et al., 2020, p. 1).

Literature on institutional voids has focused on various aspects including the difficulties and the costs that doing business in these environments entails (Garrone et al., 2019; Liedong \& Frynas, 2018), on how such voids can be overcome or addressed (Saka-Helmhout, 2020), the impact on resource commitments by MNEs (Liedong et al., 2020), on its impact on risk (Han et al., 2018), and from a strategy perspective the interplay between market and nonmarket strategies (Henisz \& Zelner, 2012; Rodgers et al., 2019; White et al., 2018; Yasuda \& Mitsuhashi, 2017).

As emerging and developing markets increasingly gain in importance within the international business arena, both as markets and as producers, so it is becoming all the more important to comprehend the effects of institutional voids on firms' behavior. Such institutional environments can still sustain economic activity, depending on the strategies that both local and multinational companies in these contexts adopt, but at a cost. Scholars have suggested that firms operating in institutional voids can find ways to either fill in or abuse existing voids (Doh et al., 2017), or accommodate or circumvent institutional constraints (Cantwell et al., 2010; Dunning \& Lundan, 2010).

How firms respond to specific institutional voids may differ in terms of their strategies and such systemic variations may stem from differences in resources or knowledge and such capabilities may not be transferable across geographies (Doh et al., 2017). Under extreme conditions of institutional voids, strategies may become less effective and firms' survival necessitate developing sensitivity to the signals and evolving rapidly, even while attempting to influence the institutional context (Feinberg et al., 2015). This points to the importance of firms actively engaging with local institutional conditions and proactively developing strategic responses to succeed in these contexts. We ask whether systematic variations in these responses to institutional voids are affected by the institutional environment of firms' home countries? 


\subsection{Strategic Responses of Firms to Institutional Voids: Why the Home Country Matters}

Institutional theory has been criticized for its assumptions of organizational passivity and its neglect of the strategic behavior and influence that organizations have on institutional development (Ma et al., 2016). Oliver (1991, p. 173) illustrates that institutional frameworks can readily 'accommodate a variety of strategic responses to the institutional environment when the degree of choice and activeness that organizations exhibit in response to institutional constraints and expectations is not assumed to be invariant across all institutional conditions.' Whilst institutional explanations emphasize the role of conformity and isomorphism, the resource-based view assumes that organizations have active agency and some degree of control over the resource environment. Oliver integrates an institutional and resource-based view (IBV and RBV) into a set of antecedents that are hypothesized to impact on organizational responses to institutional processes. These result in typologies of strategic responses to institutional processes ranging from acquiescence to active manipulation. She argues that organizational responses to institutional processes will depend on the nature of institutional pressures and their cause, as well as where they occur. Her research did not explicitly examine this in an international context but was interested in institutional influences more broadly. By not focusing on an international setting, there is no explicit accounting for possible differences that may affect strategic responses based upon whether the organization is domestic or foreign and for how notions of distance between the home and host countries may impact such considerations. Furthermore, these strategic responses were theorized rather than emerging out of empirical evidence.

Extending this research to an international business perspective, Boddewyn and Brewer (1994) discuss the interactions between firms, industries and institutional factors and raise the importance of differences in the environments in which these firms operate. They argue that whether international firms choose to comply with, avoid, or circumvent certain institutional settings depend upon a cost-benefit analysis of the relative importance and strategic salience of those markets. Furthermore, it is influenced by their ability to their leverage resources, capabilities and power to affect the uncertain institutional outcomes (also see Elsahn \& Benson-Rea, 2018; Puck et al., 2018; Voinea \& van Kranenburg, 2018). The simultaneous consideration of both resources and institutions and the interplay between the two is especially important in an international context where firms cannot assume that domestic advantages necessarily translate into foreign environments. Our research extends this reasoning to investigate the strategic responses of international firms to environments of institutional voids and in particular how the home country affects these responses.

Cuervo-Cazurra et al. (2018a, b) point out that current theories have paid inadequate attention to the impact of the multinational's home country context. There are of course significant exceptions and we highlight two that are relevant to our research. Firstly, the institutional distance literature recognizes the 'importance of national context and contextual embeddedness of organizations' and examines the impact of distance on organizational outcomes amongst other factors (see 
Kostova et al., 2019, p. 467 for a review of the literature). For example, Yan et al. (2020) explicitly investigate the role of home country institutions in international market selection and in particular how institutional embeddedness in home countries help firms overcome barriers of distance. Secondly, research on the influence of the home country on foreign direct investment through institutional learning whereby firms utilize the experience gained with the specificities of institutions at home and use this learning to their advantage in other countries (Cuervo-Cazurra $\&$ Genc, 2008). The latter resonates with our research as it implies that the home country's institutional environment may provide certain advantages or disadvantages to a firm in host countries depending on the similarity or differences between the institutional milieus.

Rugman et al. (2011) hone in on two particular advantages relevant to international business, namely the ability of firms to deploy their firm and country specific advantages (FSAs and CSAs) in different institutional settings. Firms engaging in foreign direct investment face an inherent disadvantage associated with the liability of foreignness linked to their lack of experience and familiarity in new environments and therefore need advantages to offset this liability. Specifically they need to deploy their FSAs and CSAs to compensate for disadvantages and by combining these in novel ways they can give rise to new FSAs (Hillemann \& Gestrin, 2016; Rugman et al., 2011). This is important in the presence of institutional voids where these advantages are needed in the development of unique strategic responses that are geared towards this context. Institutional voids may create an opportunity to gain advantages for those firms that have the skills and resources to address those but can also create major obstacles for those firms without the necessary abilities (Doh et al., 2017).

Banerjee et al. (2018) highlight that even when MNEs possess advantages allowing for the exportation of market strategies, the liability of foreignness remains an obstacle. They posit that though there may be a basic understanding of general market and institutional conditions, there is always a liability in being foreign in these environments associated with fully grasping the complexities in market dynamics, the socio-political situation and the appropriate responses to action, and this is especially so in institutional voids. There is therefore a debate about the relative advantages between firms based upon their home country and this has been particularly pronounced in comparisons between multinationals from advanced versus emerging markets (AMNEs versus EMNEs).

Traditionally the focus has been on expounding the advantages that AMNEs capitalize upon to navigate and become dominant in international markets through their unparalleled market power, vast resources and strategic links. Advantages include their proprietary technologies, strong global brands, good reputation, and managerial competences (Elango \& Pattnaik, 2007). However, how these advantages translate in vastly distant institutional environments as represented by voids is less clear. EMNEs, on the other hand, may fall short on a number of these traditional advantages but there is a growing literature which points to their own unique areas of advantage such as possible cost innovation capabilities, quick market responses, low-cost solutions, and potentially superior institutional resilience (Estrin et al., 2018; Holburn \& Zelner, 2010; Luo \& Bu, 2018). 
The advantages linked to EMNEs might be particularly salient in host countries with similar institutional conditions to their home experience resulting in a form of advantage associated with institutional complementarity (Luiz et al., 2017; Robertson \& Luiz, 2019). Fathallah et al. (2018) suggest that firms from home countries characterized by institutional voids and uncertainty and frequent policy changes, are relatively less sensitive to similar uncertainty associated with institutions in host countries. The knowledge and experience they gain in operating in their particular home country environments is transferred to subsidiaries operating in similar host country configurations. They go further to state that a firm's home country policies and shared experiences can even become so engrained in the organization that decision-making processes become cognitively imprinted in the minds of managers. Hence, managers develop mental models which shape their interpretation of the environment and guides their actions according to their experiences in similar situations. This can come as a benefit or cost to a firm depending on whether the policies, resource allocation and decision processes employed between the home and host countries are compatible with the situation presented by the environment. Fernández-Méndez et al. (2018) investigate a particular dimension of this by focusing on how domestic political knowledge shapes foreign expansion into host institutional environments which are similar to that of their home countries. Various threads of research therefore point to the influence of the home country and its institutions on the process of internationalization.

Aguilera and Grøgaard (2019) state that the fact that institutions matter for international business is uncontested but more research is needed in critically appraising institutions across contexts that focuses on the idiosyncratic nature of institutions and how they shape international firms' behavior. Likewise, Jackson and Deeg (2019) call for new approaches that take institutional context seriously and that a large gap still exists in overcoming decontextualized perspectives. Bringing the home country to the fore of research in international business is an important step in that direction (as has been identified by Adomako et al., 2020; Cuervo-Cazurra et al., 2018a, b) and this is likely to be especially so in emerging and developing market environments characterized by institutional voids. We bring the home country firmly into our analysis, and propose a typology of how firms from different types of home institutional frameworks respond to institutional voids within the host country, and do so in an underresearched African context.

\section{Research Methodology}

\subsection{Research Design}

The aim of this research was exploratory in nature and utilized a case studies approach. Yin (2003) states that case studies lend themselves to research focused on how or why questions and when the attention is on a multifaceted social phenomenon examining the interplay between the context and the phenomenon, as is our research. Such an approach is also very effective in extracting rich data from small sample size situations. This was suitable for this study as comparable companies 
fitting the profile of the research were very limited. Our company case studies were embedded within two countries characterized by institutional voids, thus utilizing what Yin (2003) refers to as an embedded case design.

Institutional voids, as defined by Khanna and Palepu (2010) exist in large parts of the developing and emerging world and we chose two countries in Africa as our host contexts both because it is a region which is underresearched and because institutional conditions are particularly challenging. Thereby we follow the advice of Barnard et al. (2017) in terms of the value of theorizing out of extreme contexts. In selecting our two country contexts we required them to meet several conditions based upon our research purpose. Firstly, they needed to have difficult institutional environments in which to conduct business and we examined the ease of doing business indicators produced by the World Bank and the Corruption Perception Index produced by Transparency International to guide us in this regard. We also consulted Fainshmidt et al. (2018) for their country categorization based upon institutional varieties in searching for more extreme institutional settings in terms of institutional voids. Secondly, given our focus on home country context we required the country to have AMNEs, EMNEs, and local firms operating to give us this comparative angle and we wanted these firms to meet certain minimum size thresholds as we discuss below. For these reasons, we selected the DRC and Zimbabwe. Table 1 provides comparative economic and institutional indicators for these two host locations, as well as those for the home countries of our selected companies. It indicates that the DRC and Zimbabwe perform poorly as regards institutional measures where they rank towards the bottom of countries worldwide. This is further supported by proxies for the availability of infrastructure fundamental to business activities-for example, in the DRC only $19 \%$ of the population have access to electricity. This provides some indication of the extent of the institutional voids in our two countries. As regards home locations, our selected companies represent seven countries: four advanced economies with highly developed institutions and per capita GDPs in excess of $\$ 42,000$, and three emerging markets with per capita GDPs below $\$ 8500$ and ranked in the middle section of the ease of doing business indicators (ranked 84-97 out of 190 countries). The table provides evidence of how the economic and institutional contexts compare between the home and host locations as we sought to gain institutional variation given our research question.

\subsection{Country Contexts}

Within these two countries we sought to focus on sectors that were most affected by the nature of institutional voids and where these sectors played a leading role within those economies. In the DRC this was the mining sector as conflict and civil war is particularly concentrated in areas where mining is dominant and these are areas where the government of Kinshasa exercises the least direct authority with rebel armies often in de facto control. The recent Ebola epidemic and the government's struggle to contain its spread is an example of its limited reach. Furthermore, the 2018 Mining Contribution Index shows the DRC to be the second most dependent country on mining worldwide. 


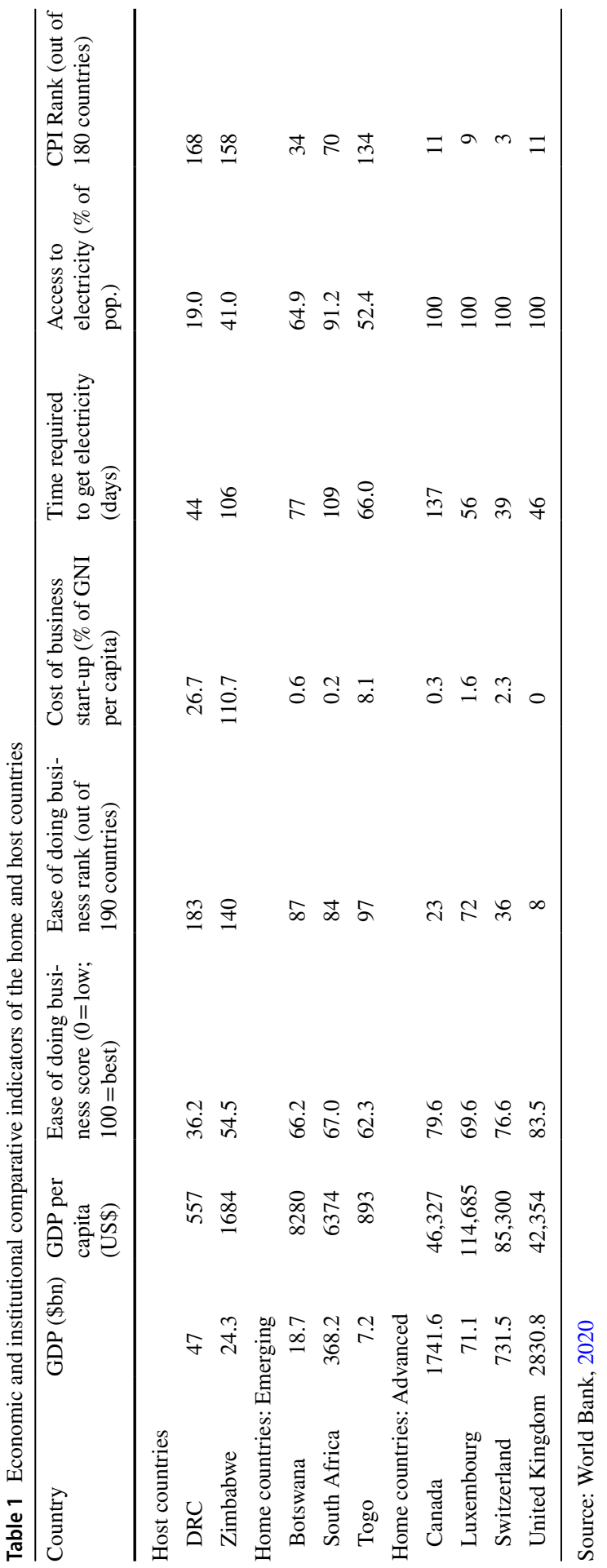


The DRC is the largest Francophone country in Africa with over 77 million inhabitants and with fewer than $40 \%$ living in urban areas (World Bank, 2018). $77 \%$ are considered to be extremely poor and live on less than USD1.90 a day (World Bank, 2018). This former Belgian colony has vast arable land and a very rich mineral endowment - the DRC possesses the potential to become one of the wealthiest countries on the continent with over 1100 minerals and precious metals (World Bank, 2018). However, the country shows high fragility; it has a fractious political setting, heightened political uncertainty, and residual security risks (Fainshmidt et al., 2018; World Bank, 2018). Both the extractive industry and the development agenda are highly politicized with systemic instability prevalent due to the contestation of power (Natural Resource Governance Institute, 2015). The business environment is characterized by high transaction costs associated with this institutional context.

As regards Zimbabwe, the services sector makes up close to $66 \%$ of the economy and its recent economic crises and hyperinflation particularly affected financial services (World Bank, 2019). Zimbabwe is a country that has seen amongst the most extreme conditions of institutional voids over the past two decades. It gained independence in 1980 and its first leader Robert Mugabe ended up in power for almost three decades only releasing that power in November 2017 during an attempted coup. Key events in the country's political economy include the following. In the mid-1980s an estimated 20,000 people were killed in Matabeleland in a massacre by Mugabe's Fifth Brigade. Between 1998 and 2002 the country actively intervened in the civil war in the DRC. After following an unsuccessful structural adjustment program in the early 1990s, this was followed by a chaotic land reform program which saw white farmers being evicted off their land without compensation and often violently. This saw a sharp drop in food production and an economic crisis resulted with shortages of basic commodities appearing. Hyperinflation resulted and at its peak in 2008 inflation was estimated at $79.6 \%$ billion per cent month-on-month or $89.7 \%$ sextillion per cent year-onyear (Hanke \& Kwok, 2009). The government was forced to stop printing its currency and switch to alternative currencies. This period coincided with high levels of violence and a clampdown on opposition movements and political and civil rights. This was accompanied by high levels of emigration and rapidly declining social indicators. The economy remains in serious condition with a foreign exchange crisis resulting in the country unable to trade freely and an increasing debt burden compounding the problems. Although the post Mugabe government has brought about some improvements to the institutional environment, investment continues to be hindered by the insecurity of land tenure, an inability to repatriate dividends abroad, and a continued lack of clarity regarding the government's Indigenization and Economic Empowerment Act.

Fainshmidt et al. (2018) provide a useful taxonomy of institutional systems for understudied countries and identify the DRC as possessing a fragmented institutional system with a fragile state. Although they do not include Zimbabwe in their study, the country would neatly fit within this category. They describe countries in this configuration (exclusively African in their categorization) as high in institutional voids, with substantial state intervention and relatively fragile federal governments 
(Luiz et al., 2019). This provides further support to our selection of these two institutional contexts given our focus on institutional voids.

\subsection{Data Collection}

Data collection lasted for 16 months over 2018 and 2019 and included interviews, company visits and archival materials. The one-on-one interviews were conducted between August and November 2018 and were mostly in-person but we used technology through Skype or Zoom where in-person interviews were not possible. The interviews were semi-structured and standardized for all participants which ensured that the same questions were asked for comparability (see Appendix). However, questions were open-ended to enable rich data exploration and to permit the free flow of the conversation while still allowing for a significant degree of comparison to be made between data collected. Interviews were conducted by at least one of the authors and lasted between 45 and 120 min. Follow-up interviews were conducted where questions of clarification arose in the transcription phase and in the data analysis. ${ }^{2}$ Interviews were recorded with the consent of the participants for transcribing and coding.

The research population for this study was composed of larger firms operating in the mining sector in the DRC and financial services in Zimbabwe for the reasons explained above. We limited it to companies that had at least total revenue of over $\$ 50$ million in the host country to ensure a significant size of operation. Given the nature of these economies, the effective population was relatively small and we thus relied upon purposive sampling that would most effectively allow us to examine our research questions. Furthermore, participants were selected purposively so as to interview those with detailed knowledge of the company strategy and operations. All respondents were in senior management positions and had been with their respective companies for at least seven years. We conducted interviews with 27 respondents across 15 companies-12 respondents in Zimbabwe (across six companies) and 15 in the DRC (across nine companies) - see Table 2 for a description of participants and company profiles. In the DRC our case studies capture all of the largest players within the mining sector, whilst in Zimbabwe it includes three of the five largest banks (the other two declined to participate) and three of the mid-sized players in the market. In Zimbabwe, all the firms had at least 25 years history in the country with some dating back over 70 years. In the DRC, it is slightly more complicated because of various buyouts but these investments in the country for all, bar one company, took place between 1996 and the early-2000s. The one exception is the last mentioned Canadian firm in the table which operated there since 2017. All the AMNEs and EMNEs covered in both countries had prior experience in doing business in emerging markets and in at least two other African countries.

\footnotetext{
${ }^{2}$ All interviews were conducted in English. This was not an issue in Zimbabwe where English is one of the official languages and it was not an issue at any of the MNEs operating in either country. In the case of the two local companies in the DRC we offered to conduct the interviews in French but respondents were fluent in English and preferred for the interviews to proceed in English.
} 


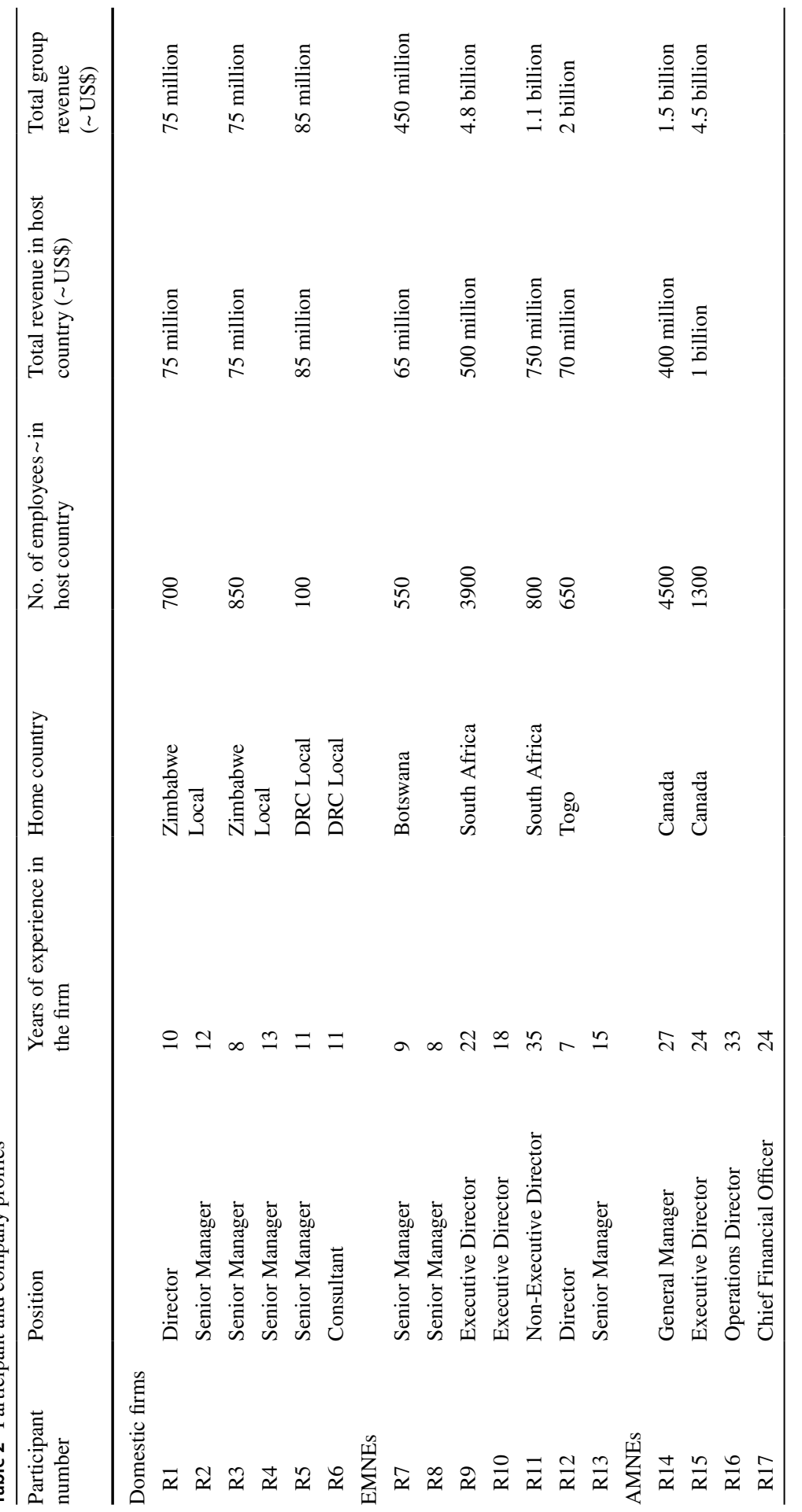




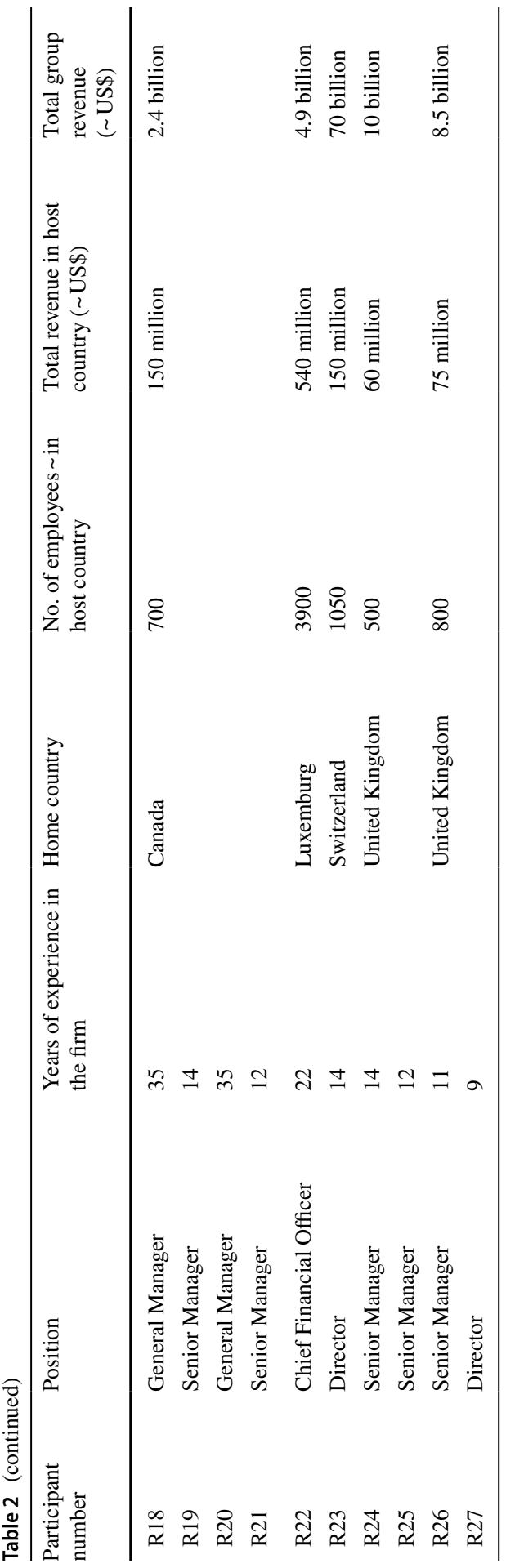




\subsection{Data Analysis}

The data analysis employed thematic coding which involved the categorization of transcribed data from the interviews into common themes. After data was transcribed and organized, initial reading occurred where broad ideas were noted. We followed the template proposed by Gioia et al. (2013) whereby we first coded inductively maintaining the integrity of first-order terms (informant centric). These were structured around the nature of institutional voids in these contexts and how it affected their operations where terms such as 'politically turbulent and politically charged', 'terrible legislation and very unclear', and 'non-functional ecosystem' came to the fore. This was followed by questions on how they coped and developed strategic responses to these voids. To ascertain how these actions grouped into responses and thus to form our second-order themes (Gioia et al., 2013) we engaged in a process of constant comparison between theory and data and this process was more deductive in nature (Gond et al., 2018) as it relied on pre-existing work on international strategic responses. However, we also found activities that did not fit into pre-existing forms of prior work and these were labelled to give 'meaning in relation to strategy', relying on relevant literatures whenever possible (Gond et al., 2018, p. 248). Figure 1 presents the data structure that resulted from our analysis. It provides first-order categories from respondents of how the institutional environment impacted upon their business and the practices they utilized to deal with these challenges. These first-order categories were then combined to create theoretical constructs related to the strategic responses to institutional voids.

Validation strategies were used together with reliability checks as follows. Credibility was ensured by the closeness of participants to the environment with all participants being senior managers with direct exposure to the impact of the institutional context on firms' strategic responses. The research safeguarded internal validity through the data analysis process. Responses were triangulated against secondary data to confirm interviewee perspectives and in order to develop a truthful chronology of events. Data obtained was compared to information in company annual reports and other archival material to substantiate the findings. In order to maximize dependability, all interviews were conducted based on clear protocols and the procedures of these interviews were documented to ensure replicability. Interviews were audio recorded and transcribed verbatim to reduce researcher bias and to help ensure consistency in coding and data analysis. Assurance of the anonymity and confidentiality of interviews was guaranteed to participants which made the interviews more open, reducing subject or participant bias.

\section{Findings: Strategic Responses to Institutional Voids}

Respondents from both countries highlighted the difficulties of doing business in the host environments, in particular as regards the heightened political uncertainty and risk, corruption, lacking social and physical infrastructure, and unreliable regulations, amongst others. The unpredictability of the institutional environment and the ambiguous and dynamic nature of the rules of the game as per Khanna and Palepu's 


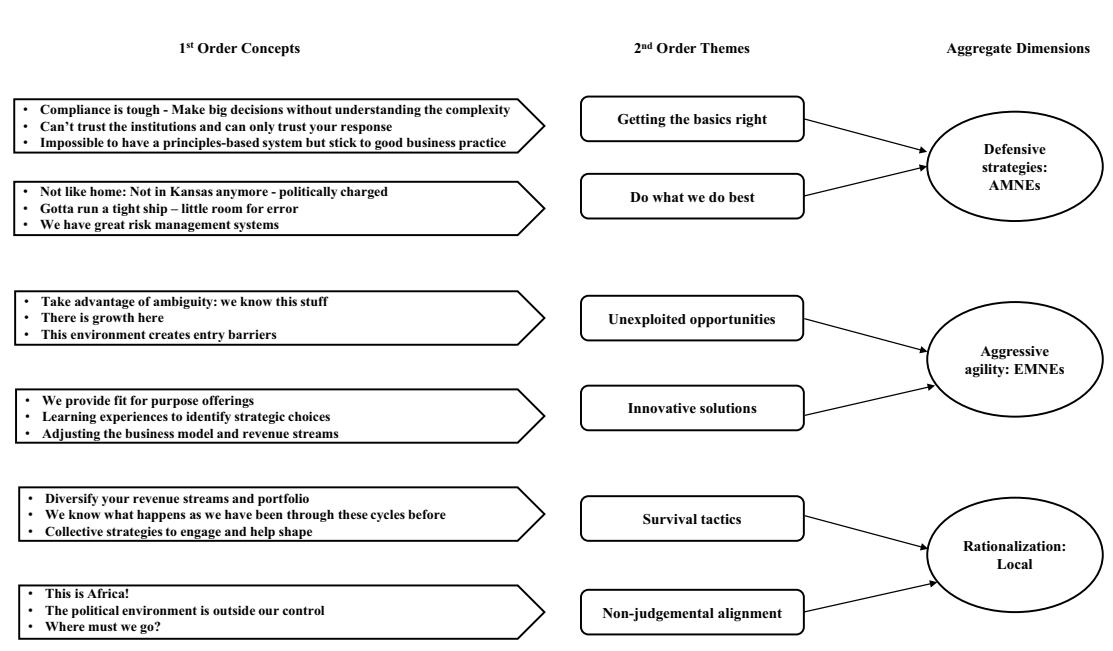

Fig. 1 Data structure

(2010) institutional voids increased the transaction costs of doing business. This put pressure on firms to adapt and to respond appropriately to the institutional voids. Our thematic analysis of the interviews revealed a number of responses employed by firms as presented in Table 3. Firms utilized different elements to give themselves the ability to at times just survive and at other times to thrive in this environment-moving between states of hibernation and forceful opportunism. Although firms utilized a combination of these strategies, we see home country effects. The institutional environment of their home country appeared to frame both their perception of and their strategic responses to the voids. We explore this below.

\subsection{Strategic Responses of AMNEs}

Respondents from AMNEs pointed out the challenges and vulnerabilities they faced in operating in such institutionally voided environments and stressed the advantages of more stable institutional settings. They highlighted the consequence of the regulations, the rules of the game, and economic and political stability and their frame of reference was the predictability of rules in their home country-i.e., the familiar and wanting to 'operate in a manner that is consistent with best practice' (R24) and 'where there's policy consistency and clarity' (R26).

Respondents stressed the difficulties of operating in these two countries and that they struggled with the ambiguity of the rules of the game which made it difficult for them to operate because of the lack of consistency and their unfamiliarity of operating in such contexts:

There's this constant threat that's just sort of lurking over you, where you know that you're not compliant to every single rule that they have, (and) they can dig out something (R22). 
Table 3 Differential strategic responses to institutional voids (RAD)_-illustrative quotes from interviews

Differential strategic responses Illustrative and supportive quotes

Defensive (D)

But there are times when you have to exit relationships ... at risk of losing so we do adjust on a continual basis (R24)

We continually review our risk appetite. We've got risk appetite metrics that define the amount of risk that we are prepared to take so were we find that we're taking risk, we adjust our strategy in terms of our target market and the amount of business that we underwrite, to align with our expectations (R26)

Don't do marginal projects. There are poor institutional capacities, lack of investment infrastructure etc. (Therefore) the cost of doing business is high. You cannot solve the inefficiencies alone, you are going to absorb them; you will need to be left with some margin left. So, you must pick a good project with a good return and execute the plan (R15)

You want to look at the general political environment as far as governance and policy is concerned. Investors prefer a country where there's policy consistency and clarity (R26)

So you cannot deploy those resources in an environment where you can't plan, in an environment where you cannot really recoup your return on investment. So you tend to want to minimise the amount of risk in the investments that you're making. So institutional considerations are important and we don't plan in a vacuum (R24)

Aggressive agility (A)

So, in a way the current institutional environment of unavailability of forex has enabled us to develop specific products for this market. We realized we had a good exporter book, a supportive regulator and a huge base of importers seeking to import products into the country. So, we organized trade structures to support these three parties as a strategy. Hence we have now shifted our strategy from just general services to trade focused services (R13)

I spoke a bit about price controls especially on interest rates so how we have related to that as a business is that we have tried to create a mix of the type and source of revenues to concentrate less on the revenues that are controlled. We are growing our non-interest revenue because there we have more room to charge economic rates (R12)

Strategy are choices that you make. So given the choices that you have to make there are alternatives and opportunity costs that you incur. They can also have cascading effects, so you then find that because of that your strategy should be fluid to adjust. Strategy at the end of the day in the twenty-first century is not static but fluid (R7)

[We have] leeway to take certain aggression and to take certain risk because we know we are covered .... Policies often change overnight so the best way to just manage it is to adjust your target market strategy as you go ...you can't really pre-empt policy because, you don't know what policy is going to come out before it actually comes out. You almost react as it comes through ... So, strategy can result from the institutional arrangements (R12) 
Table 3 (continued)

Differential strategic responses Illustrative and supportive quotes

Rationalization (R) We look at the political environment in terms of the stability of government and its policies. And by stability of government it does not necessarily mean that we are in agreement nor disagreement but it is purely from a stability perspective (R4)

What we have been doing as well is to push most of our staff members to participate in some of the lobby groups that are within the country. For instance, we have got strong representation on [mentions three bodies which their managers chair or are board members of]. So we try to have as much representation as possible in all the regulatory bodies and lobby groups so that our positions can be explained (R1)

The political environment is something that is outside our control. So we have to deal with whatever comes through but we can now often anticipate. For instance, if we are going towards elections, we have gone through so many cycles now, we know what happens immediately after elections so we are to an extent prepared (R4)

So they make big, big decisions without understanding the complexity. ... They've brought in legislation which we actually can't really comply with. Not even almost, it is definitely impossible to comply fully with the new legislation (R16).

These companies saw little opportunity to address the sources of the voids themselves and respondent 15 was explicit in this respect by saying 'you cannot solve the inefficiencies alone, you are going to absorb them'. Participants highlighted the importance of excelling with strategies that ensure that a 'tight ship is run' (R27) as there is 'little room for error' (R25) in such environments. They explained that a necessary but not sufficient condition lies with mastering the market operations to compensate for the additional risk of operating in these settings.

They also emphasized not counting on the institutions themselves to address the problems which inevitably arose. For example, respondent 22 speaking on the judicial system explained that it is: "not going to help you and you have to really think about whether you want to go to court or not and many circumstances the answer is you don't want to go to court because ... the court proceedings themselves are very expensive ... and the outcome is dubious.'

These firms demonstrated a key concern around security and institutional stability. They developed strong strategic business relationships with a number of international companies in the country that shared similar home country origins- the utilization of a common lens and a common defensive platform. Their approach mostly concentrated on robust risk management which capitalized upon their inherent FSAs:

...management of risk, maturity transformation and ensuring that resources are allocated to the best possible use. As long as you do that effectively though withstanding the risk in the environment we as a business we should also be able to continue to run as a going concern' (R24). 
We continually review our risk appetite. We've got risk appetite metrics that define the amount of risk that we are prepared to take so where we find that we're taking risk, we adjust our strategy (R26).

You are a multinational-you are part of a bigger group and you've got resources outside there, access to lines of credit, you've got resources in terms of access to knowledge and products that are probably more sophisticated (R25).

The desire was to operate in as predictable a context as possible as that played to their traditional strengths.

They explicitly deliberated on how they could continuously affect their bargaining power relative to the government authorities mindful of protecting their assets from expropriation which was always top of mind. They reflected on how they could make themselves more indispensable to the local authorities and how they could leverage that by capitalizing upon their FSAs. For example, through their 'provision of vital lines of international credit and foreign currency for the country or access to [our] foreign resource networks more generally' (R27).

Participants indicated the importance of creating and enhancing the social licence to operate. They argued that institutional voids together with the history of colonialism (see Glaister et al., 2020) and civil wars, and economic and social deprivation meant that investors needed to work with and develop the communities where they operate. Not doing so would harm investors in the long-term. Often this would require them to deliver services which fall into the government realm but because of its incapacity the expectation was that these companies fill that void. For example, some provided electricity, education or health care to the broader community free of charge.

In general their approach can be categorized as defensive, and even resorting to forms of hibernation when voids and uncertainty become extreme. This meant reducing their market activities and only engaging in maintaining and protecting their most critical clients and sources of revenue when necessary. Their frame of reference was associated with their home countries and their predictable rules of the game and finding ways to leverage their traditional FSAs and CSAs. Respondent 24 reflecting on their approach relative to that of local firms stated that 'local banks are more aggressive you know. They want to grow but if you look at their balance sheets the level of loan-losses or none performing loans that they carry is a reflection of their strategy.' He explained that as a British listed company they would be averse to taking on such additional risk in such institutional environments and would deliberately slow down business activity to reduce risk when appropriate: 'If we are comfortable with that then we do business but if we believe that the strategy is not effective we exit such a relationship or we just don't engage because they do not fit into our profile of acceptable risk.' During the same interview he pointed out that the consequence of maintaining an appropriate risk profile in such institutionally voided environments was that they had to turn away business and watch their competitors gain market share: 'You know we haven't had major transactions in quite a long time ... But there are times when you have to exit relationships ... at risk of losing so we do adjust on a continual basis.' 


\subsection{Strategic Responses of EMNEs}

Respondents from EMNEs stressed the opportunities that existed in these markets and stated that it played to their strengths in that they were better able to absorb institutional voids given their home country environments which often also reflected institutional weaknesses although not to these extremes. Their focus was on growth opportunities in these unsaturated markets. Furthermore, the institutional voids provided entry barriers to other firms which increased the sense that there were unexploited opportunities to be capitalized upon. The respondents argued that they had particular strengths that they could capitalize upon relative to both AMNEs and local firms. Relative to AMNEs, which they saw as more risk averse, their shareholders were more likely to fund riskier growth than the shareholders of AMNEs and that the latter often found it hard to raise funding from their traditional financial institutions. Interestingly, respondents from AMNEs also alluded to this and that they struggled to raise financing from Western sources and that if it were not for Chinese financial institutions and partners they would find it very hard to do business in these locales: 'So it's not your typical analyst or institutional investor that's going to run when he sees risk, it's your long-term, strategic investor which is going to walk through that difficult time and reap big rewards later. ... You're only getting it basically from the Chinese, who I think are, in the world, probably one of the best nations looking at long-term strategy and managing difficult climate and difficult circumstances in Africa. If it wasn't for them, I don't think there'd be any investment at all that we could afford to make' (R16). Against local firms they had the advantage of pan-African networks 'which put us way ahead of our local competitors because we are able to do cross-border transactions that local companies can only dream of doing' (R12) and whilst local firms had to bear the full brunt of the institutional risk, they had a more diversified portfolio which meant that they had extra 'leeway to take certain aggression and to take certain risk because we know we are covered' (R12).

The focus of our EMNEs was not on institutional voids but rather on the growth opportunities that exist behind this. Their home country experience provided them with improved capabilities in terms of managing uncertainty along the lines proposed by Cuervo-Cazurra et al. (2018a, p. 219) who write of these capabilities as a form of 'contextual knowledge' that is applicable to diverse situations. Luiz et al. (2017) refer to this as capabilities associated with 'institutional complementarity'similarities between home and host institutional conditions facilitating the exploitation of capabilities associated with these environments.

For these EMNEs it was about their agility and ability to quickly adjust to a position that maximized their value creation in that particular market. Their fluid, agile strategies were a competitive advantage well suited to poor institutional environments and helped them to be competitive. They engaged in dynamic and aggressive approaches directed at managing both the results of institutional voids and also the source of these voids using a combination of strategies. Firstly, opportunistic entrepreneurialism related to the institutional voids by providing new goods and services which often compensated for these voids. Respondent 13, reflecting on their experience in Zimbabwe during the periods of hyperinflation and shortages of foreign 
exchange in the country, spoke about how they adjusted their product offerings to mitigate this impact and take advantage of unexpected opportunities:

So, in a way the current institutional environment of unavailability of forex has enabled us to develop specific products for this market. We realized we had a good exporter book ... and a huge base of importers seeking to import products into the country. So, we organized trade structures to support these parties as a strategy. Hence we have now shifted our strategy from just general services to trade focused services (R13).

Secondly, bridging gaps or institutional voids by adopting new systems and solutions. For example, in Zimbabwe shortages of cash and hyperinflation have seen financial services go fully digital and seen bank branches closing down whilst designing new technology solutions. Respondent 12, a director at one of West Africa's largest banks, lamenting the absence of a credit reference bureau in Zimbabwe explained how they adapted to this information asymmetry as they experienced similar conditions in other countries that they did business in:

That's an institutional challenge ... you don't have anything so it's a void, it's non-existent so we have responded to this and different ways we were basically doing informal enquiries amongst Banks. So if you've got a new company that is coming on board and you are thinking of giving them money you can informally talk to your friends at (another bank) saying guys, what do you think of this person? Have you given them money before? Have they been performing on their loan so what you will find is people are generally very cooperative because next time they know they will be able to call in a favor as well so it's a very informal arrangement which tries to fill in that void (R12).

In the DRC, some firms have taken advantage of infrastructure deficits by vertically integrating into service lines that would assist in maintaining control over value chains (as suggested by Bucheli \& Kim, 2015). In order to export minerals out of the country, miners vertically integrated and invested in logistics themselves. By creating logistics divisions, firms internalized the cost in order to control the value chain better and reduce the uncertainty about the share of the value that they expected to appropriate. Whilst mining companies could not shift the production elsewhere as they were tied to the resource base they actively shifted some of their value addition activities offshore.

Thirdly, our EMNEs engaged in diverse activities to directly mitigate the impact of institutional voids. These strategies were aimed less at trying to change the institutional landscape, as the space for doing so was not seen to be viable, and thus it was more around mitigation: 'The causes we can't do much unfortunately because these are macroeconomic issues' (R12). This included lobbying policymakers through business associations to adjust policies that were detrimental to business, or bridging voids by collaborating with sector regulators to facilitate greater efficiency in transactions within the sector: 'if we have major issues with the regulator, the state or any other institution like the tax authority, we lobby collectively as an industry. I think it works fairly well' (R7). 
Lastly, partnerships were widely employed with firms using hybrid structures, and joint ventures and alliances. This included collaborating with partners outside the country to facilitate cross border transactions which could help unlock bottlenecks and reduce transactions costs: 'We collaborate significantly with our sister affiliates in the region. Then we also do serious collaborations with the group in support of our local business' (R12).

In the $\mathrm{DRC}$, there is a legal requirement to share shareholding with the state for mining, and each mine had joint venture agreements with the state-owned mining company, Gecamines. Some partnerships were mutually beneficial and participants highlighted the importance of public-private partnerships involving infrastructure development as an example. Over the last few years, mining companies have taken part in investment in the power sector as a lack of electricity was considered a significant limiting factor to production by miners. Mines have sought to pre-finance the refurbishment of some old power stations with the promise of receiving their investment back through power credits. Such agreements are becoming frequent in DRC where private-public partnerships are created in order to reach a win-win situation-the DRC is unable to raise cheaper funding in the capital markets, whilst miners are able to tap into their resources in order to pave the way for their energy needs in the future.

The findings demonstrate that these EMNEs expanded into these markets to take advantage of opportunities and make use of the learnings they have gained from operating in their own tough home country institutional environments. This allowed them to create prospects within the market to gain market share in these conditions and provide services and solutions that were needed in the host country. Their adaptations to the voids were aggressive, opportunistic and agile:

Policies often change overnight so the best way to just manage it is to adjust your target market strategy as you go ...you can't really pre-empt policy because, you don't know what policy is going to come out before it actually comes out. You almost react as it comes through (R12).

\subsection{Strategic Responses of Domestic Firms}

Domestic firms demonstrated a process of rationalizing institutional voids and saw instability as part of operating in African markets more generally and therefore focused on the upside local potential. This approach was associated with the significant exposure that they have to the environment and not having the luxury to opt out through geographic repositioning. In terms of market strategies they resorted to diversification, not of geography, but of the business itself. By diversifying their domestic portfolio in terms of their offerings they attempted to reduce the risks that come with depending on one country: 'continuing to work diversifying our income streams or our portfolio' (R3). Given the difficulty of escape they needed to make it work and thus resorted to significant hedging with financial instruments and adapting business processes to deal with the institutional voids: 'We have been investing heavily in government paper. It's a survival tactic' (R2). There was also more of a placatory approach towards government because of their exclusive dependence on 
this market: 'it does not necessarily mean that we are in agreement nor disagreement but it is purely from a stability perspective' (R4).

These local firms worked hard to ensure that their interests were heard and engaged in extensive stakeholder management and lobbying to help shape policy: 'we push most of our staff members to participate in some of the lobby groups that are within the country' (R1). They showed a preference for favoring out-of-court settlements as a form of maintaining control of litigation issues, and preferred negotiations as a form of dealing with problems and avoiding getting into fights with political actors. They utilized collective strategies to share resources through coordination with other players for the creation of positive externalities or the abatement of negative externalities. This was often coordinated through chambers of business which sought not only to defend the interests of its members but also to facilitate their cooperation with economic and social development activities. This was not always successful and some participants indicated that chambers could be captured by government aligned interests. For example, in the DRC the body which was supposed to defend the interests of the industry was headed by the CEO of the state-owned miner with close ties to the President and some respondents felt that this created a conflict of interest. This was hard to bypass given the fact that the state-owned miner had a compulsory carry on all mining activities.

Firms' responses showed a sense of resignation to the institutional environment and a rationalization of what it means for their business: 'The political environment is something that is outside our control. So we have to deal with whatever comes through but we can now often anticipate. For instance, if we are going towards elections, we have gone through so many cycles now; we know what happens immediately after elections so we are to an extent prepared' (R4).

\section{Discussion}

In this paper, we theorize that the institutional environment of firms' home countries affect their strategic responses to institutional voids in host emerging or developing markets. Our company case studies, represented seven countries, with diverse institutional settings as presented in Table 1. We suggest that firms' familiarity, or lack thereof, with institutional voids in their home country impact upon their perception of such institutional conditions and that it provides a 'sense-making' lens which they apply in their responses. Our categories map onto the theoretical dimensions of Oliver's (1991) strategic responses to institutional pressures but are also distinctive given that our focus is international and is premised on the interplay between the home and the host environment. We identify differences in the strategic responses of AMNEs, EMNEs and domestic firms associated with the impact of this institutional complementarity between their home and host country environments. By bringing in the international context we can account for notions of institutional distance and examine whether similarities and differences affect strategic responses thereby incorporating an additional lens to Oliver's institutional pressures. We show that the strategic responses of our sampled firms to institutional voids are characterized by rationalization for domestic firms (R), EMNEs by aggressive agility (A), and 
AMNEs by defensiveness (D) (RAD). Local firms are embedded in the domestic environment and as insiders they are most keenly attuned to the particular institutional voids, whilst AMNEs are the most institutionally distant to the host environment and as outsiders to these institutional voids they are more defensive in their strategic responses, and lastly, EMNEs have some familiarity with similar institutional contexts and recognize certain complementarities between their home and the host settings which affect their strategic responses.

Local firms demonstrated greater levels of what Oliver (1991) refers to as acquiescence with some elements of compromise. They were more likely to follow and accept the taken for granted norms and to comply with the rules although with efforts to make their voices heard through collective strategies by negotiating with institutional stakeholders in a nonthreatening manner. EMNEs revealed more of what Oliver refers to as manipulation whereby they attempted to co-opt influential constituents and shape values and criteria but also elements of compromise as they balanced the expectations of multiple constituents recognizing that they needed to adapt and accommodate local institutional elements. AMNEs came closest to Oliver's avoidance, not through complete escape but by avoiding certain risks and giving up market share. They exhibited some elements of compromise especially in utilizing their FSAs for tactical bargaining with institutional stakeholders by making themselves indispensable in terms of the resources they could offer. By focusing on what they did well and their resource advantages they also tactically were able to better conceal or disguise nonconformity.

Table 4 unpacks this RAD framework of strategic responses structured around the institutional complementarity between home and host settings. AMNEs' strategic responses were defensive in nature and associated with their superior FSAs and risk management. But their level of discomfort with institutional voids, given low levels of contextual knowledge, and their search for predictability in the rules of the game imply certain disadvantages linked to their lower level of embeddedness in the host environment. In other words, they have a greater liability of foreignness due to the institutional distance. In terms of our sampled firms, they were more likely to turn away business and lose market share to maintain a desired risk ceiling in such institutionally voided contexts.

On the other hand, EMNEs capitalized on their knowledge of less institutionally stable contexts and adopted aggressively agile strategic responses to what they perceived as the opportunities presented by these settings. Lastly, local companies have less international diversification and opportunity to escape and therefore have to work within these environments and to rationalize and reconcile with and embed their strategic responses within the context. What they lack in resources they make up for with their high contextual knowledge allowing them to leverage their resources effectively.

Our theoretical contribution is as follows. Whilst Oliver (1991) hypothesized antecedents that impact on organizational responses to institutional processes, she did so from a theoretical perspective rather than with empirical research and she did not explicitly account for an international context. Boddewyn and Brewer (1994) extend this to an international setting and study the interactions between firms and institutional settings but their analysis is firmly rooted on one side of the coin, 
Table 4 Strategic responses to institutional voids, institutional complementarity and the home country

\begin{tabular}{llll}
\hline & AMNE & EMNE & Local \\
\hline Institutional void & Outsider & Familiar & Insider \\
Rules of the game & Seek predictability & Seek complementarity & Seek reconciliation \\
FSA: Resources & High & Medium & Low \\
CSA: Contextual & Low & Medium/high & High \\
Embeddedness & Low & Medium & High \\
Strategic response & Defensive & Aggressive & Rationalization \\
\hline
\end{tabular}

namely the host institutional conditions. Our contribution is to show the dynamics of why the home institutional environment may impact upon the strategic responses of firms to institutional voids in host markets and thereby brings in an additional dimension. Furthermore, our institutional setting is extreme as we highlight understudied economies within the developing world that have diverse and unique institutional environments (Fainshmidt et al., 2018). Given that Oliver's theorization does not analyze an international setting, possible differences between home and host institutional pressures are not examined and how these might affect the strategic responses of firms. The consequence of this is apparent upon closer examination of her hypotheses which do not account for how institutional pressures might be affected by institutional distance. For example, she hypothesizes that the likelihood of organizational resistance to institutional pressures is greater, the 'greater the degree of discretionary constraints imposed on the organization by institutional pressures' (p. 164), and the 'lower the level of uncertainty in the organization's environment' (p. 170). We highlight that such responses are affected by how a firm's home country environment may help frame their understanding of these institutional pressures. By virtue of similarities and differences between the home and the host context, a firm can be an insider or outsider or something in-between to environments beset by institutional voids, and we argue that this may impact upon those hypothesized responses. We show that AMNEs are most likely to respond in the hypothesized manner as their frame of reference is a home context of well-functioning institutions with predictable rules of the game and this leads to higher levels of resistance in institutionally voided settings. Local firms, on the other hand, as insiders that are deeply embedded in that institutional context and have little room for escape are likely to interpret the rules of the game differently and will seek some form of reconciliation with those rules. Lastly, EMNEs which have some familiarity with difficult institutional environments see certain complementarities between their home and their host contexts which allow them greater agility in recognizing and taking advantage of opportunities. In this way we are able to add additional nuance, evidence and dimensions to Oliver's theorization.

Secondly, we contribute towards the literature on the effects of a firm's home country on internationalization (Cuervo-Cazurra et al. 2018a, b; García-Canal \& Guillén, 2008; Luo \& Wang, 2012). We show how the home context impacts firms' strategic responses to institutional voids and provide an explanation for 
why this may be the case. Whilst there are increasing calls to take context more seriously in management research, in our study context is paramount (Doh et al., 2012; Hamann et al., 2020). We see firms' abilities to operate in these environments and to exploit their inherent FSAs defined by the context. This institutional context is associated with higher transaction costs or what Dorobantu et al. (2017) refer to as 'institutional costs' and the lack of predictability and security of investment and operations. The volatility and ambiguity of the rules of the game imply that firms may not be able to rely on their existing models and routines structured around their FSAs as they may not translate effectively in this milieu. Newman (2000) supports this notion stating that in extreme institutional contexts existing resources and capabilities may be rendered less relevant. This does not imply that FSAs are unimportant but rather that firms cannot assume that they can exploit them as per usual because their effectiveness may be neutered by the challenging institutional environment (Barbour \& Luiz, 2019).

Whilst prior research points to the importance of FSAs in overcoming the liability of foreignness, the nature of our institutional environments is such that the ability of firms to exploit these FSAs may be compromised as they translate less seamlessly. The institutional voids may provide certain advantages to local firms or EMNEs which have more familiarity with such conditions as they can capitalize upon their knowledge and experience and take advantage of institutional complementarity. Newman (2000) states that the foreignness of more extreme institutional contexts implies that firms (we would argue AMNEs) lack legitimate templates to process and interpret information and activity. The institutional voids create ambiguity in cause-effect relationships which may result in strategic confusion. This confusion is less pronounced for firms that have experiences and capabilities from the past that are relevant to this institutional context. Firms have to make sense of the rules of the game and their ability to process and understand the ambiguity is impacted by their level of embeddedness in this institutional framework and their prior experience of such institutions.

Thirdly, we contribute towards the literature on institutional voids in emerging markets (Khanna \& Palepu, 2010; Meyer \& Peng, 2016; Wang et al., 2020) and we extend this towards the study of less developed markets-in Africa in our case (Boso et al., 2019; Zoogah et al., 2015). As the continent grows in importance so it becomes all the more imperative for us to understand the challenges of doing business in such settings and how it affects the ability of firms to succeed under these conditions. Furthermore, given the increasing presence of MNEs in Africa (Parente et al., 2019) it is important that we further understand the advantages and disadvantages that investors will face-in particular whether EMNEs or AMNEs are better positioned to exploit these opportunities and to leverage their FSAs most effectively. We provide nuance on the impact of institutional voids and demonstrate that it does not necessarily affect the strategic responses of firms in the same manner. We suggest that the home country institutional context may mitigate the impact of institutional voids in host markets and may affect the ability of firms to leverage their sources of advantage. We illustrate the differences in the strategic responses in institutionally voided environments between AMNEs, 
EMNEs and domestic firms and thereby contribute to our understanding of differences between these firms in terms of their FSAs and CSAs.

\section{Conclusion}

Our research suggests that firms' strategic responses to institutional voids in emerging or developing markets are affected by the home country's institutional environment and firms' experiences and advantages arising from that home context. Firms adopt strategic responses which reflect their respective advantages and this results in diverse approaches based on the interplay between capitalizing upon internal resources and institutional know-how. Strategic responses to institutional voids reflect constrained optimization-effectively utilizing a combination of internal resources adapted to the external environment. For some firms this may result in a defensive posture whilst for others opportunistic and aggressive agility, or rationalization and reconciliation, and the extent of this is influenced by the home country and its institutional conditions.

Our study has implications for practice. Firstly, managers should note the dangers of assuming that FSAs necessarily translate into institutionally voided locations but should rather start with the context and interpret and develop responses that speak to that context. This requires fully integrating both a resource and institution-based analysis of firms' underlying advantages. Secondly, we demonstrate the scope for firms to adopt solutions-driven approaches that attempt to fill institutional voids (Gao et al., 2017). We show that how they do so is impacted by their home country with local firms more likely to engage in negotiation and reconciliation, whilst AMNEs capitalize upon the bargaining power associated with their extensive international resources. This leads to our third practical implication which is the importance of a partnership-driven approach to institutional voids (Doh et al., 2012, 2017; Dorobantu et al., 2017). We propose that how firms engage in such partnerships is impacted by their home country and their experience of partnerships (hybrid and otherwise). For example, whilst local firms rely extensively on meaningful representation on official business-government forums and bodies to represent, coordinate and negotiate their positions, EMNEs engage in innovative partnerships with a wider range of stakeholders aimed at mitigating some of the institutional risks. Our research also demonstrates the difficulty of such partner-driven approaches where such bodies are often 'compromised' by governments-as in the DRC where the chamber of business mining was headed by the CEO of the state-owned mining company creating conflicts of interest.

Several limitations manifest as regards this research which leads to areas for future research. The nature of the sample in terms of countries, firms and sectors selected mean that we cannot generalize but that was not the purpose of this research which was exploratory in nature. Future research could extend this by exploring how it generalizes to other settings and sectors. Even within Africa we selected two countries characterized by more severe institutional voids but, as we highlighted in Table 1, there is a continuum of institutional environments and this requires further nuanced analysis. Additionally, more work of a longitudinal nature will allow us to explore the dynamics 
of how strategic responses adapt to institutional voids. We know that institutional environments are not static and thus how firms' strategic responses interact and are affected by institutional changes requires more work. Furthermore, our focus was on the strategic responses and not on the relative success of these responses and this lends itself to future research. Related to this, our research only touches on the connected nature of market and nonmarket strategies although it is not something we actively investigated. Mellahi et al. (2016) argue that more work is needed in this area and particularly how the combination of market and nonmarket strategies can result in unique capabilities. We lack a mid-theory that shows MNE organizational adaptation processes using combinations of nonmarket and market capabilities or development phases and all the more so in particularly trying institutional environments that are subject to continuous change. Our research proposes that such an analysis needs to account for differences in the home country's institutional context of firms.

\section{Appendix: Interview Guide}

1. What key institutional considerations are important in running your business in this context?

2. If a foreign firm: How are the institutions in this context similar or different to your home country?

3. Have these institutions provided challenges to the way in which to do business here and if so how?

4. Do these institutional arrangements influence company strategy and if so, how?

5. If institutional challenges identified then: What strategic responses has your company taken in order to manage or mitigate these challenges?

6. Relative to your competitors in this market, do you think your firm is better or worse positioned to respond to the institutional context and how so?

7. Relative to your competitors in this market, has your strategic response to the institutional environment differed to theirs? If so, how and why?

8. If a foreign firm: What influence does your home country have in how you view the institutional context here relative to your competitors?

9. What sort of links and connections have you built up with various stakeholders in this market and how have these influenced your strategic response to the institutional environment? How would you describe how your approach differs or is similar to that of your competitors?

10. What would be the key advice you would give another firm considering entering this market?

\section{Declarations}

Conflict of interest None of the authors have any conflict of interest or funding information specific to this research to declare. 
Open Access This article is licensed under a Creative Commons Attribution 4.0 International License, which permits use, sharing, adaptation, distribution and reproduction in any medium or format, as long as you give appropriate credit to the original author(s) and the source, provide a link to the Creative Commons licence, and indicate if changes were made. The images or other third party material in this article are included in the article's Creative Commons licence, unless indicated otherwise in a credit line to the material. If material is not included in the article's Creative Commons licence and your intended use is not permitted by statutory regulation or exceeds the permitted use, you will need to obtain permission directly from the copyright holder. To view a copy of this licence, visit http://creativecommons.org/licen ses/by/4.0/.

\section{References}

Adomako, S., Amankwah-Amoah, J., Dankwah, G. O., Danso, A., \& Donbesuur, F. (2019). Institutional voids, international learning effort and internationalization of emerging market new ventures. Journal of International Management, 25(4), 1-12.

Adomako, S., Frimpong, K., Danso, A., Amankwah-Amoah, J., Uddin, M., \& Kesse, K. (2020). Home country institutional impediments and international expansion of developing country SMEs. International Business Review, 29(5), 101716.

Aguilera, R. V., \& Grøgaard, B. (2019). The dubious role of institutions in international business: A road forward. Journal of International Business Studies, 50(1), 20-35.

Banerjee, S., Venaik, S., \& Brewer, P. (2018). Analysing corporate political activity in MNC subsidiaries through the integration-responsiveness framework. International Business Review, 28(5), 1-18.

Barbour, O., \& Luiz, J. (2019). Embracing solutions-driven innovation to address institutional voids: The case of Uber and the middle of the pyramid. California Management Review, 62(1), 31-52.

Barnard, H., Cuervo-Cazurra, A., \& Manning, S. (2017). Africa business research as a laboratory for theory-building: Extreme conditions, new phenomena, and alternative paradigms of social relationships. Management and Organization Review, 13(3), 467-495.

Barnard, H., \& Luiz, J. M. (2018). Escape FDI and the dynamics of a cumulative process of institutional misalignment and contestation: Stress, strain and failure. Journal of World Business, 53(5), $605-619$.

Boddewyn, J. J., \& Brewer, T. L. (1994). International-business political behavior: New theoretical directions. Academy of Management Review, 19(1), 119-143.

Boso, N., Adeleye, I., Ibeh, K., \& Chizema, A. (2019). The internationalization of African firms: Opportunities, challenges, and risks. Thunderbird International Business Review, 61(1), 5-12.

Bucheli, M., \& Kim, M. (2015). Attacked from both sides: A dynamic model of multinational corporations' strategies for protection of their property rights. Global Strategy Journal, 5(1), 1-26.

Cantwell, J., Dunning, J. H., \& Lundan, S. M. (2010). An evolutionary approach to understanding international business activity: The co-evolution of MNEs and the institutional environment. Journal of International Business Studies, 41(4), 567-586.

Chen, R., Cui, L., Li, S., \& Rolfe, R. (2017). Acquisition or greenfield entry into Africa? Responding to institutional dynamics in an emerging continent. Global Strategy Journal, 7(2), 212-230.

Cuervo-Cazurra, A., \& Genc, M. (2008). Transforming disadvantages into advantages: Developingcountry MNEs in the least developed countries. Journal of International Business Studies, 39(6), 957-979.

Cuervo-Cazurra, A., Ciravegna, L., Melgarejo, M., \& Lopez, L. (2018a). Home country uncertainty and the internationalization-performance relationship: Building an uncertainty management capability. Journal of World Business, 53(2), 209-221.

Cuervo-Cazurra, A., Luo, Y., Ramamurti, R., \& Ang, S. (2018b). The impact of the home country on internationalization. Journal of World Business, 53(5), 593-604.

Cuervo-Cazurra, A., Mudambi, R., \& Pedersen, T. (2019). Clarifying the relationships between institutions and global strategy. Global Strategy Journal, 9(2), 151-175.

Doh, J., Lawton, T., \& Rajwani, T. (2012). Advancing nonmarket strategy research: Institutional perspectives in a changing world. Academy of Management Perspectives, 26(3), 22-39. 
Doh, J., Rodrigues, S., Saka-Helmhout, A., \& Makhija, M. (2017). International business responses to institutional voids. Journal of International Business Studies, 48(3), 293-307.

Dorobantu, S., Aseem, K., \& Benner, Z. (2017). Nonmarket strategy research through the lens of new institutional economics: An integrative review and future directions. Strategic Management Journal, 38(2), 114-140.

Dunning, J. H., \& Lundan, S. M. (2010). The institutional origins of dynamic capabilities in multinational enterprises. Industrial and Corporate Change, 19(4), 1225-1246.

Elango, B., \& Pattnaik, C. (2007). Building capabilities for international operations through networks: a study of Indian firms. Journal of international business studies, 38(4), 541-555.

Elsahn, Z. F., \& Benson-Rea, M. (2018). Political schemas and corporate political activities during foreign market entry: A micro-process perspective. Management International Review, 58(5), 771-811.

Estrin, S., Meyer, K. E., \& Pelletier, A. (2018). Emerging economy MNEs: How does home country munificence matter? Journal of World Business, 53(4), 514-528.

Fainshmidt, S., Judge, W. Q., Aguilera, R. V., \& Smith, A. (2018). Varieties of institutional systems: A contextual taxonomy of understudied countries. Journal of World Business, 53(3), 307-322.

Fathallah, R., Branzei, O., \& Schaan, J. L. (2018). No place like home? How EMNCs from hyper turbulent contexts internationalize by sequentially arbitraging rents, values, and scales abroad. Journal of World Business, 53(5), 620-631.

Feinberg, S., Hill, T. L., \& Darendeli, I. S. (2015). An institutional perspective on non-market strategies for a world in flux. In T. C. Lawton \& T. S. Rajwani (Eds.), The Routledge companion to non-market strategy (pp. 29-46). Routledge.

Fernández-Méndez, L., García-Canal, E., \& Guillén, M. F. (2018). Domestic political connections and international expansion: It's not only 'who you know' that matters. Journal of World Business, 53(5), 695-711.

Gao, C., Zuzul, T., Jones, G., \& Khanna, T. (2017). Overcoming institutional voids: A reputation-based view of long-run survival. Strategic Management Journal, 38(11), 2147-2167.

García-Canal, E., \& Guillén, M. F. (2008). Risk and the strategy of foreign location choice in regulated industries. Strategic Management Journal, 29(10), 1097-1115.

Garrone, P., Piscitello, L., \& D’Amelio, M. (2019). Multinational enterprises and the provision of collective goods in developing countries under formal and informal institutional voids. The case of electricity in sub-Saharan Africa. Journal of International Management, 25(2), 1-17.

Geleilate, J. M. G., Magnusson, P., Parente, R. C., \& Alvarado-Vargas, M. J. (2016). Home country institutional effects on the multinationality-performance relationship: A comparison between emerging and developed market multinationals. Journal of International Management, 22(4), 380-402.

Gioia, D. A., Corley, K. G., \& Hamilton, A. L. (2013). Seeking qualitative rigor in inductive research: Notes on the Gioia methodology. Organizational Research Methods, 16(1), 15-31.

Glaister, K. W., Driffield, N., \& Lin, Y. (2020). Foreign direct investment to Africa: Is there a colonial legacy? Management International Review, 60(3), 315-349.

Gond, J. P., Cabantous, L., \& Krikorian, F. (2018). How do things become strategic? "Strategifying" corporate social responsibility. Strategic Organization, 16(3), 241-272.

Hamann, R., Luiz, J., Ramaboa, K., Khan, F., \& Dhlamini, X. (2020). Neither colony nor enclave: Calling for dialogical contextualism in management and organization studies. Organization Theory., 1(1), 1-21.

Han, X., Liu, X., Gao, L., \& Ghauri, P. (2018). Chinese multinational enterprises in Europe and Africa: How do they perceive political risk? Management International Review, 58(1), 121-146.

Hanke, S. H., \& Kwok, A. K. (2009). On the measurement of Zimbabwe's hyperinflation. Cato Journal, 29(2), 353-364.

Henisz, W. J., \& Zelner, B. A. (2012). Strategy and competition in the market and nonmarket arenas. Academy of Management Perspectives, 26(3), 40-51.

Hillemann, J., \& Gestrin, M. (2016). The limits of firm-level globalization: Revisiting the FSA/CSA matrix. International Business Review, 25(3), 767-775.

Holburn, G. L. F., \& Zelner, B. A. (2010). Political capabilities, policy risk, and international investment strategy: Evidence from the global electric power generation industry. Strategic Management Journal, 31(12), 1290-1315.

Hoskisson, R. E., Wright, M., Filatotchev, I., \& Peng, M. W. (2013). Emerging multinationals from midrange economies: The influence of institutions and factor markets. Journal of Management Studies, 50(7), 1295-1321. 
Jackson, G., \& Deeg, R. (2019). Comparing capitalisms and taking institutional context seriously. Journal of International Business Studies, 50(1), 4-19.

Khanna, T., \& Palepu, K. (1997). Why focused strategies may be wrong for emerging markets. Harvard Business Review, 75, 41-54.

Khanna, T., \& Palepu, K. G. (2010). Winning in emerging markets: A road map for strategy and execution. Harvard Business Press.

Kostova, T., Beugelsdijk, S., Scott, W. R., Kunst, V. E., Chua, C. H., \& van Essen, M. (2019). The construct of institutional distance through the lens of different institutional perspectives: Review, analysis, and recommendations. Journal of International Business Studies, 51(4), 467-497.

Liedong, T. A., \& Frynas, J. G. (2018). Investment climate constraints as determinants of political tie intensity in emerging countries: Evidence from foreign firms in Ghana. Management International Review, 58(5), 675-703.

Liedong, T. A., Peprah, A. A., Amartey, A. O., \& Rajwani, T. (2020). Institutional voids and firms' resource commitment in emerging markets: A review and future research agenda. Journal of International Management, 26(3), 1-21.

Liu, W., \& Li, J. (2019). Unbalanced Institutions in market transition: How do they matter for firm strategic choices and performance in emerging economies? Management International Review, 59(5), 675-702.

Luiz, J. M., Ganson, B., \& Wennmann, A. (2019). Business environment reforms in fragile and conflictaffected states: From a transactions towards a systems approach. Journal of International Business Policy, 2(3), 217-236.

Luiz, J. M., Stringfellow, D., \& Jefthas, A. (2017). Institutional complementarity and substitution as an internationalization Strategy: The emergence of an African multinational giant. Global Strategy Journal, 7(1), 83-103.

Luo, Y., \& Bu, J. (2018). Contextualizing international strategy by emerging market firms: A composition-based approach. Journal of World Business, 53(3), 337-355.

Luo, Y., \& Wang, S. L. (2012). Foreign direct investment strategies by developing country multinationals: A diagnostic model for home country effects. Global Strategy Journal, 2(3), 244-261.

Ma, X., Ding, Z., \& Yuan, L. (2016). Subnational institutions, political capital, and the internationalization of entrepreneurial firms in emerging economies. Journal of World Business, 51(5), 843-854.

Mellahi, K., Frynas, J. G., Sun, P., \& Siegel, D. (2016). A review of the nonmarket strategy literature: Toward a multi-theoretical integration. Journal of Management, 42(1), 143-173.

Meyer, K. E., Estrin, S., Bhaumik, S. K., \& Peng, M. W. (2009). Institutions, resources, and entry strategies in emerging economies. Strategic Management Journal, 30(1), 61-80.

Meyer, K. E., \& Peng, M. W. (2016). Theoretical foundations of emerging economy business research. Journal of International Business Studies, 47(1), 3-22.

Mol, M. J., Stadler, C., \& Ariño, A. (2017). Africa: The new frontier for global strategy scholars. Global Strategy Journal, 7(1), 3-9.

Natural Resource Governance Institute. (2015). Democratic Republic of Congo. Country Strategy Note, $1-14$.

Newman, K. L. (2000). Organizational transformation during institutional upheaval. Academy of Management Review, 25(3), 602-619.

North, D. (1990). Institutions, institutional change and economic performance. Cambridge University Press.

Oliver, C. (1991). Strategic responses to institutional processes. Academy of Management Review, 16(1), 145-179.

Parente, R., Rong, K., Geleilate, J. M. G., \& Misati, E. (2019). Adapting and sustaining operations in weak institutional environments: A business ecosystem assessment of a Chinese MNE in Central Africa. Journal of International Business Studies, 50(2), 275-291.

Puck, J., Lawton, T., \& Mohr, A. (2018). The corporate political activity of MNCs: Taking stock and moving forward. Management International Review, 58(5), 663-673.

Robertson, N., \& Luiz, J. M. (2019). Exploiting emerging market complementarities: Delayed, then accelerated internationalisation in a technology EMNE. Multinational Business Review, 27(1), 54-76.

Rodgers, P., Stokes, P., Tarba, S., \& Khan, Z. (2019). The role of non-market strategies in establishing legitimacy: The case of service MNEs in emerging economies. Management International Review, 59(4), 515-540.

Rugman, A. M., Verbeke, A., \& Nguyen, Q. T. (2011). Fifty years of international business theory and beyond. Management International Review, 51(6), 755-786. 
Saka-Helmhout, A. (2020). Institutional agency by MNEs: A review and future research agenda. Journal of International Management, 26(2), 1-17.

Voinea, C. L., \& van Kranenburg, H. (2018). Feeling the squeeze: Nonmarket institutional pressures and firm nonmarket strategies. Management International Review, 58(5), 705-741.

Wang, D., Cui, L., Vu, T., \& Feng, T. (2020). Political Capital and MNE Responses to Institutional Voids: The case of Chinese state-owned enterprises in Africa. Organization Studies, 1-22 (forthcoming).

White, G. O., Boddewyn, J. J., Rajwani, T., \& Hemphill, T. A. (2018). Regulator vulnerabilities to political pressures and political tie intensity: The moderating effects of regulatory and political distance. Management International Review, 58(5), 743-769.

World Bank. (2018). World Bank Country profile: Democratic Republic of Congo. World Bank.

World Bank. (2019). World Bank Development Indicators. World Bank.

World Bank. (2020). World Bank Development Indicators. World Bank.

Yan, H., Hu, X., \& Liu, Y. (2020). The international market selection of Chinese SMEs: How institutional influence overrides psychic distance. International Business Review, 29(4), 101703.

Yasuda, N., \& Mitsuhashi, H. (2017). Learning from political change and the development of MNCs' political capabilities: Evidence from the global mining industry. Management International Review, 57(5), 749-774.

Yin, R. K. (2003). Case study research and applications: Design and methods. Sage Publications.

Zoogah, D. B., Peng, M. W., \& Woldu, H. (2015). Institutions, resources, and organizational effectiveness in Africa. Academy of Management Perspectives, 29(1), 7-31.

Publisher's Note Springer Nature remains neutral with regard to jurisdictional claims in published maps and institutional affiliations. 